\title{
A restauração arquitetônica na década de 1980 no Brasil a partir dos exemplos da Revista do Patrimônio Histórico e Artístico Nacional
}

Architectural restoration in the 1980s in Brazil based on examples from Revista do Patrimônio Histórico e Artístico Nacional

https://doi.org/10.1590/1982-02672020v28d2e40

\author{
BEATRIZ MUGAYAR KÜHL' \\ https:// orcid.org/0000-0003-4290-1934 \\ Universidade de São Paulo / São Paulo, SP, Brasil
}

RESUMO: Este artigo trata de questões relacionadas ao restauro arquitetônico nos anos 1980 no Brasil a partir dos exemplos que aparecem nos números da Revista do Patrimônio Histórico e Artístico Nacional daquela década. $O$ intuito é evidenciar formas como questões de restauro ali aparecem e problematizar o discurso em torno dos exemplos publicados. Ainda faltam no Brasil estudos que tratem de forma sistemática o conjunto das restaurações feitas no país naquele período, apesar de existirem análises sobre obras específicas de grande interesse. $\bigcirc$ objetivo deste texto não é fazer apresentação metódica do quadro de intervenções daquele momento, mas problematizar alguns temas a partir daquilo que a então Secretaria do Patrimônio Histórico e Artístico Nacional (Sphan) (atual Instituto do Patrimônio Histórico e Artístico Nacional - Iphan) valorizou em sua revista, especialmente dois casos ali publicados - a proposta de ação prevalentemente conservativa nas Ruínas de São Miguel das Missões e a intervenção no Paço Imperial do Rio de Janeiro -, contrabalançados por outros textos do periódico. Para tanto, será inicialmente explicitada a forma de circunscrição do tema e de sua abordagem para, a seguir, apresentar algumas características da Revista do Patrimônio nos anos 1980. Depois, serão enfrentados os artigos sobre as Ruínas de São Miguel e sobre o Paço Imperial que, na sequência, serão contrabalançados com outros discursos em torno deles e com outros textos que aparecem naqueles mesmos números, os quais tratam de diversas questões de preservação e lançam luzes mais matizadas sobre o que se discutia sobre restauração naquela década.

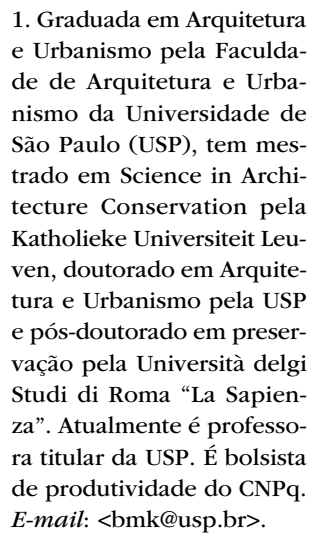

1. Graduada em Arquitetura e Urbanismo pela Faculdade de Arquitetura e Urbanismo da Universidade de São Paulo (USP), tem mestrado em Science in Architecture Conservation pela Katholieke Universiteit Leuven, doutorado em Arquitetura e Urbanismo pela USP e pós-doutorado em preservação pela Università delgi Studi di Roma "La Sapienza”. Atualmente é professora titular da USP. É bolsista de produtividade do CNPq. E-mail: <bmk@usp.br>. 
PALAVRAS-CHAVE: Bens culturais. Restauração. Revista do Patrimônio Histórico e Artístico Nacional.

ABSTRACT: This article analyzes issues related to the architectural restoration in 1980s Brazil, exploring examples published in various editions of Revista do Patrimônio Histórico e Artístico Nacional of that decade to verify the methods used to handle restoration problems and question the arguments related to these examples. Brazil still lacks studies that systematically treat the restorations made in the country during that period, although analyses of great interest concerning specific interventions exist. The purpose of this text is not to present systematically the preservation issues of that time, but to question some themes that Sphan (Secretaria do Patrimônio Histórico e Artístico Nacional, current Instituto do Patrimônio Histórico e Artístico Nacional - Iphan) valued in its journal, especially two cases published there: the predominantly conservative proposal for the Ruins of São Miguel das Missões, and the intervention in the Imperial Palace of Rio de Janeiro, counterbalanced by other texts of the journal. For such, the approach to the theme will be initially explained. Then, the characteristics of Revista do Patrimônio in the 1980s will be presented. Afterwards, the articles about the Ruins of São Miguel and the Imperial Palace are analyzed and then counterbalanced with other articles that present different discourses around these cases and other approaches that appear in those issues of the journal. These articles deal with various preservation problems and add nuance on what was being discussed about restoration in that decade.

KEYWORDS: Cultural heritage. Restoration. Revista do Patrimônio Histórico e Artístico Nacional. 


\section{RESTAURAÇÃO NO BRASIL NA DÉCADA DE 1980: CIRCUNSCRIÇÃO DA ABORDAGEM E ALGUNS QUESTIONAMENTOS}

Enfrentar o tema da restauração na década de 1980 no Brasil é um grande desafio, em especial pelo fato de ainda faltarem pesquisas que tratem de modo abrangente os casos de restauração arquitetônica naqueles anos. Apesar de haver uma sólida produção científica sobre temas de preservação no Brasil e sobre a trajetória dos órgãos de preservação², ainda faltam estudos transversais voltados especificamente para a restauração naquele decênio. Esses estudos transversais, associados aos estudos monográficos sobre exemplos específicos que se estão avolumando, possibilitarão uma visão extensa das intervenções realizadas nas obras arquitetônicas consideradas de interesse cultural naquele período. ${ }^{3}$

Alguns casos foram bastante emblemáticos e pautaram diversas discussões naquela época e até hoje, como, na cidade de São Paulo, as ações no Teatro Municipal - cujas intervenções, nos anos 1950, 1980 e 2010 estão sendo perscrutadas em profundidade pela pesquisa de mestrado de Beatriz Fernandes Vaz Oliveira, orientada por Maria Lucia Bressan na Faculdade de Arquitetura e Urbanismo da Universidade de São Paulo (FAUUSP) - e no Sesc Pompeia (1977-1986), conduzidas por Lina Bo Bardi. Este último caso, apesar de se voltar a uma edificação que, na época, não era reconhecida oficialmente como bem cultural, recai no campo do restauro a pleno título pelo fato de se tratar de um complexo de interesse para a cultura e feito de acordo com os princípios de intervenção do campo do restauro.

Existem, ainda, os estudos sobre intervenções em cidades e conjuntos tombados, cujo olhar se estende por um arco temporal alargado, que abrange também a década de 1980. Estão sendo realizados em instituições de ensino e pesquisa e no próprio Instituto do Patrimônio Histórico e Artístico Nacional (lphan), tendo por parâmetro os estudos coordenados por Lia Motta ${ }^{4}$ sobre Ouro Preto, divulgados num artigo da Revista do Patrimônio Histórico e Artístico Nacional que se tornou paradigmático ao abordar a atuação da então Secretaria do Patrimônio Histórico e Artístico Nacional (Sphan) ${ }^{5}$ naquela cidade. Pode ser citado, por exemplo, o doutorado de Carolina Fidalgo de Oliveira sobre a cidade de Goiás, defendido em 2016 na FAUUSP e recentemente publicado como livro. Nele, a autora aborda os diferentes argumentos mobilizados no processo de patrimonialização da cidade dos anos 1950 até a sua candidatura a Patrimônio Mundial da Organização das Nações Unidas para a Educação, a Ciência e a Cultura (Unesco), que se efetivou em 2001. Mesmo que a autora tenha se centrado em três momentos que identifica como os principais para abordar os problemas propostos la década de 1950, finais
2. A trajetória do Instituto do Patrimônio Histórico e Artístico Nacional (Iphan) tem sido explorada de modo aprofundado por diversos autores, tanto em artigos quanto em teses e livros, resultantes das mais variadas instituições de ensino e pesquisa no Brasil, inclusive do próprio Mestrado Profissional em Patrimônio Cultural promovido pelo Iphan. Abordar essa ampla produção escapa aos objetivos deste artigo, mas, apenas a título de exemplo e para referências bibliográficas complementares, cf. Chuva (2009), Fonseca (1997), Marins (2016) e Sant'Anna (1995). Para uma leitura recente do Iphan na própria Revista do Patrimônio Histórico e Artístico Nacional, ver as diversas contribuições presentes no número 35, de 2017.

3. É necessário especificar que, neste artigo, estão sintetizadas na palavra "restauro", ou "restauração", as ações - fundamentadas do ponto de vista da construção do campo disciplinar - sobre os bens de interesse para a preservação, reconhecidos ou não oficialmente como tal por meio do tombamento. A palavra "preservação" é aqui entendida num sentido alargado de discussões e ações em torno dos bens culturais, que passa por temas como políticas públicas de reconhecimento, discussões sobre identidade cultural e memória, inventário, propostas normativas e também pelas ações diretas nos bens, que assumem denominações como "manutenção", "conservação" e "restauro". Aqui, as ações serão sintetizadas no vocábulo "restauro", denominação do campo disciplinar que se ocupa das intervenções nos bens culturais.

4. Cf. Motta (1987) 
5. Na década de 1980 , o atual Iphan era a Secretaria do Patrimônio Histórico e Artístico Nacional (Sphan), denominação que perdurou de 1979 a 1990. A Sphan funcionava de modo dual com a Fundação Nacional Pró-Memória, que existiu naquele mesmo período de 1979 a 1990, com o intuito de oferecer maior dinamismo às políticas voltadas ao patrimônio cultural (Rezende et al., 2014). Deve-se lembrar que, na sua criação, o Sphan era Serviço do Patrimônio Histórico e Artístico Nacional. Sobre a trajetória do órgão e suas diversas vicissitudes existe uma bibliografia muito ampla. Cf., por exemplo, as citadas publicações de Chuva (op. cit.), Fonseca (op. cit.) e Sant'Anna (op. cit.), e o número 35 , de 2017 , da Revista do Patrimônio.

6. Cf. Oliveira (2019).

7. Daqui em diante a Revista do Patrimônio Histórico e Artístico Nacional será mencionada apenas como Revista do Patrimônio.

8. Sobre a Revista do Patrimônio e seu papel existe também uma ampla bibliografia. Ver, por exemplo, Ribeiro (2013), Silva (2010) e Thompson et al. (2012).

9. Cf., por exemplo, Andrade (1993) e Fonseca (op. cit.). dos anos 1970 e a virada do século XX para o XXI), a década de 1980 aparece em debates e intervenções realizados em alguns dos bens da cidade. ${ }^{6}$

Apesar de numerosas contribuições de grande interesse que se estão avolumando, vindas das mais variadas instituições, ainda não temos uma visão abrangente e sistematizada que permita uma análise profunda do conjunto das restaurações feitas em bens culturais arquitetônicos na década de 1980. Restam, como mencionado, muitas pesquisas a serem feitas nesse sentido.

Desse modo, para este artigo, escolheu-se como forma de abordagem do tema a análise das propostas e intervenções feitas em edifícios de interesse cultural que são apresentadas nas edições da Revista do Patrimônio Histórico e Artístico Nacional da década de 1980: do número 19, de 1984, ao 22, de 1987, lembrando que o número 18 havia sido publicado em 1978 (o único na década de 1970) e o número 23 seria publicado somente em 1994. A escolha é baseada no fato de a revista ser um dos principais veículos de difusão e de debates sobre o patrimônio no país, se não o principal, e ter desempenhado, sem dúvida, papel dos mais relevantes para colocar os temas relacionados ao patrimônio, à identidade e à memória num lugar de destaque no período da redemocratização. Os quatro números publicados durante os anos 1980 são da mais alta importância, com numerosos artigos de qualidade e interesse que foram, na época, e se tornariam, depois, incontornáveis para o debate sobre questões patrimoniais no país. ${ }^{8}$

A proposta inicial deste estudo era centrar a análise nos casos de intervenção em obras arquitetônicas apresentados nos números publicados naquela década. O recorte escolhido, porém, mostrou-se problemático logo de saída, pois os casos apontam para dois caminhos extremos: a aproximação eminentemente conservativa nas propostas para as ruínas da lgreja de São Miguel das Missões (publicadas no número 19); e a ação mais invasiva - questionada naquele próprio momento - no caso do Paço Imperial do Rio de Janeiro (tema publicado no número 20). Esses dois casos, se examinados isoladamente do restante dos artigos e das discussões da Revista do Patrimônio, e mesmo daquilo que já se conhece de modo estruturado sobre o que foi feito no Brasil naquela década, dariam a impressão - ou construiriam uma falsa noção - de que as discussões e os modos de atuar nesse período permaneceram semelhantes aos do Sphan na chamada "fase heroica" - as Ruínas de São Miguel passaram por ação conservativa ainda no final da década de 1930, a partir das propostas de Lucio Costa, mas o modo de atuar que prevalecia em muitas das obras conduzidas pelo órgão naquele período tendia à busca de um estado idealizado, ${ }^{9}$ à semelhança do que ocorreu no Paço (tema a ser explorado adiante). Ou, ainda, dariam a impressão de estarmos presos aos 
extremos oitocentistas das visões opostas de John Ruskin e de Eugène Emmanuel Viollet-le-Duc sobre restauração.

Mas, assim como a produção sobre a história do restauro tem feito, nas últimas décadas, uma releitura crítica das construções historiográficas do campo - que, desde finais do século XIX, buscaram prevalentemente enfatizar os extremos do que ocorria naquela centúria, e não evidenciar suas nuanças -, é necessário um esforço em relação a esses casos que aparecem nas páginas da Revista do Patrimônio.

No que se refere à história da restauração, podemos pensar, por exemplo, na construção feita por Camillo Boito, em 1884,10 e por Gustavo Giovannoni, em 1936, ${ }^{11}$ de uma narrativa - depois retomada pelos mais diversos autores ao longo do século XX - que apresenta o restauro oitocentista quase que exclusivamente concentrado em dois polos antitéticos: um pautado na conservação estrita, representado por Ruskin; e outro, representado por Viollet-le-Duc, caracterizado pela busca de um estado completo idealizado, mesmo que com isso fosse necessário destruir diversos estratos incorporados à obra ao longo do tempo que se tornaram parte de sua percepção. Boito e Giovannoni advogam para si próprios a construção de uma teoria intermediária que, ao mesmo tempo que preconiza a máxima atenção com a manutenção e consolidação, insiste no respeito pelos vários estratos da obra resultantes de seu transcurso ao longo do tempo.

Muitas vezes os historiadores da restauração deixaram de evidenciar devidamente as diversas posturas que existiam à época e seus muitos matizes (mesmo tendo prevalecido, na prática e em diversos ambientes culturais, as intervenções que buscaram um estado completo idealizado), o que nos deixa, no presente, com uma visão limitada do que foi a discussão e a prática de restauração no século XIX. ${ }^{12}$ Um exemplo de revisão recente é oferecido por Françoise Choay, que, em texto intitulado "As relações entre Ruskin e Viollet-le-Duc, ou a longa vida dos preconceitos", mostra a admiração e o respeito recíprocos que Ruskin e Violletle-Duc nutriam um pelo outro no que concerne ao conhecimento da arquitetura medieval, não obstante suas posturas irreconciliáveis sobre o restauro. ${ }^{13}$

É bom mencionar que as discussões sistemáticas de mais de dois séculos sobre a restauração, com muitas releituras críticas sobre o tema, têm dado ênfase, desde algumas propostas da segunda metade do século XIX, ao respeito pelos aspectos documentais das obras e pelas suas várias fases ao longo do tempo. Respeito que, em especial nas últimas décadas do século $X X$, em âmbito internacional e no Brasil, se estende também aos aspectos memoriais e simbólicos. A visão atual sobre restauro é um desdobramento dessa construção e está articulada à discussão sobre o que é patrimônio e por que ele deve ser preservado, algo que varia com o decorrer do tempo. $\bigcirc$ interesse, atualmente, está voltado não apenas
10. Boito (2002, p. 56-61).

11. Giovannoni (2013, p. 194-195)

12. Para uma visão mais abrangente e matizada do período e da construção do restauro como campo disciplinar, cf. Carbonara (1997) e Jokilehto (1999).

13. Cf. Choay (2012, tradução minha). 
14. Os desdobramentos atuais das discussões sobre preservação e restauro são também objeto de uma farta reflexão e produção científica tanto em âmbito nacional como no exterior. Para citar apenas dois autores, no Brasil, cf. Carsalade (2018) e Castriota (2009). Do âmbito internacional, deve-se destacar a repercussão que tem no Brasil e em diversos países a produção de Muñoz Viñas (2004), que evidencia diversos atores sociais, por vezes silenciados nas discussões sobre preservação, mas constrói sua tese com asserções problemáticas do ponto de vista da reflexão do campo: proclama sua teoria como contemporânea e coloca-se como ruptura, o que implica declarar as outras formulações como superadas, negando a própria reflexão historiográfica que, desde inícios do século $\mathrm{XX}$, enfatiza continuidades, e não apenas cisões. Ao centrar sua definição de restauro em procedimentos, e não em princípios, como é a tradição do campo, o autor não oferece diretrizes conceituais para a solução de conflitos, que estão sempre presentes. Para uma análise crítica minuciosa das propostas de Muñoz Viñas, evidenciando seus múltiplos equívocos ao analisar a história da restauração e as diversas inconsistências de sua "teoria contemporânea”, ver Carbonara (2018).

15. Cf. Choay (2001, 2011).

16. Carta de Atenas... (2001).

17. Carta de Veneza... (1987). Para questões relacionadas às cartas patrimoniais e em particular à Carta de Veneza, sua fundamentação, objetivos e apreensão, cf. Kühl (2010) e Pane (2011).

18. Sigla de International às obras excepcionais e isoladas, como prevaleceu no século XIX, mas também a testemunhos do fazer humano que passam a ser considerados de interesse cultural. ${ }^{14}$

O restauro consolida-se num processo de maturação muito lento, que se amplifica a partir do século XVIII, com diversas experiências práticas de intervenção, elaborações teóricas, realização de inventários e propostas de leis. Considera-se que o restauro adquire estatuto epistemológico, no início do século XX, com as propostas de Alois Riegl de 1903. ${ }^{15}$ É considerado, desde então, campo disciplinar autônomo, com seus próprios referenciais teóricos, metodológicos e técnico-operacionais, mas não isolado, pois necessariamente deve ser articulado a vários outros campos do saber.

É importante lembrar, na construção do restauro como campo disciplinar autônomo, que, desde o final do século XIX, conforme texto normativo italiano - com as resoluções do IV Congresso de Engenheiros e Arquitetos, de 1893, adotadas pelo Ministério da Educação -, restaurar não é voltar ao passado, mas respeitar as várias fases de um mesmo bem. Num contexto internacional, isso é explicitado no documento conhecido como Carta de Atenas de restauração, de $1931,{ }^{16}$ e reiterado na Carta de Veneza, de 1964, ${ }^{17}$ adotada em 1965 pelo lcomos $^{18}$ como seu documento-base. Trata-se de uma construção cultural do campo, que se afasta da acepção comum da palavra "restauro" - que é a volta a um estado anterior ou original - e, a partir de suas próprias bases teóricas, metodológicas e técnico-operacionais, explicita que a obra parte de certo estado e é conduzida a outro, respeitando-se seus aspectos documentais, sua configuração, sua materialidade e sua estratificação ao longo do tempo, e que prefigura a ação a ser empreendida pelo projeto. ${ }^{19}$

No entanto, mesmo entre os países que seguem documentos como a Carta de Veneza enquanto referência para intervenções e discussões, é recorrente encontrar exemplos de ações que, em busca de um suposto estado original, não respeitam a configuração da obra como foi estratificada ao longo do tempo, seus aspectos documentais, tampouco suas formas de recepção. Noutras palavras, exemplos como o do Paço Imperial não tiveram um ocaso nos anos 1980 no Brasil, pois muitas vezes no discurso e na prática relacionados ao patrimônio ainda transparecem dificuldades de levar em conta manifestações posteriores à presumida fase original, em especial manifestações do ecletismo e do historicismo tardios, como nas intervenções feitas em pleno século XXI no Convento de Santo Antônio, no Rio de Janeiro. Nas obras, iniciadas em 2007, a igreja do Convento teve o frontão neocolonial das primeiras décadas do século XX, depois modificado pelo Sphan nos anos 1950, substituído por um frontão triangular que remete ao que existia originalmente, a despeito da longa presença de sua fachada de meados do século XX na paisagem da cidade. ${ }^{20}$ Isso não ocorre apenas no Brasil. Para citar apenas um exemplo, na França ambiente cultural com longa tradição de debates no campo e país-sede do lcomos 
Internacional -, basta ver a nova construção do Castelo de Blandy-les-Tours. Com origens no século XIII, a partir do século XVIII o castelo foi paulatinamente abandonado, até que, já em ruínas, foi declarado monumento histórico ainda no século XIX. Em 1992, o Conselho da região de Seine-et-Marne comprou o castelo e realizou uma vasta campanha de reconstrução, resultando num castelo imaginário. Foi retomada a forma de atuar de Viollet-le-Duc, ${ }^{21}$ tão criticada naquele país desde finais do século XIX e que levou a uma revisão do modo de agir no restauro.

Assim, mesmo com todo o debate e a construção teórica e prática plurissecular que qualificam a restauração como campo disciplinar autônomo há mais de um século, persistem posturas que não levam em conta as contribuições do próprio campo, que preconiza o respeito pela obra tal como foi historicizada no tempo, em seus aspectos materiais, documentais e de conformação. É comum descartar, de forma pouco justificável, determinadas manifestações culturais - como o ecletismo e o neocolonial - não devidamente apreciadas por certos profissionais que atuam com bens culturais, ainda que isto ocorra com menor desenvoltura do que ocorria no século XIX e nas primeiras décadas do século XX. É uma questão que persiste no presente e não pode ser tomada apenas como problema isolado de manifestações tardias de uma visão leduciana na virada do século XX para o XXI.

Nesse sentido, basta ver discussões e ações em relação ao patrimônio do movimento moderno valorizado pela historiografia e pela crítica, o qual recorrentemente não tem seu transcurso no tempo entendido como algo a ser preservado. Com frequência essas obras são remetidas a um estado original idealizado, muitas vezes até diferente daquele de fato construído, mas semelhante ao divulgado em revistas e livros consagrados. ${ }^{22}$ Esse é um modo de atuar definitivamente leduciano, e muitas vezes os autores não percebem a ironia de a vanguarda do século XXI remontar ao século XIX, isto é, a forma de atuação preconizada por eles no século XXI para o modernismo canônico é algo que teve seu apogeu no século XIX, cuja produção arquitetônica foi tantas vezes criticada e pouco compreendida por alguns dos historiadores do moderno.

Por isso, ao examinar as intervenções relatadas nos números da Revista do Patrimônio nos anos 1980, é necessário contrabalançar os casos publicados com outros discursos de diversos textos que aparecem nesses mesmos números, os quais tratam de diferentes questões de preservação e de restauro do patrimônio edificado. Esses textos lançam luzes mais matizadas sobre o que se discutia a respeito de restauração naquela década, sem recair nos polos extremos para que apontam os dois casos em tela. É relevante também recordar que no número 22 da revista foi publicada a tradução da Carta de Veneza, documento que assimila, do ponto de vista da aproximação metodológica do restauro, sítios arqueológicos, ruínas, obras
Council on Monuments and Sites (Conselho Internacional de Monumentos e Sítios), criado em 1965 e acolhido como órgão consultor e de colaboração pela Unesco.

19. Para discussões desses temas, cf. Carbonara (1997) e Kühl (2018).

20. Para uma descrição pormenorizada dessas obras, em que a fachada dos anos 1920, modificada pelo Iphan na década de 1950 , foi reconduzida a feições que remetem à sua fachada original, ver Coelho (2018).

$\mathrm{O}$ autor é plenamente favorável à obra realizada, argumentando que ela segue os princípios contemporâneos de preservação propagados pela Unesco e pelo Icomos e que recupera a "legítima identidade da Igreja" (ibid., p. 43, 49). As transformações dos anos 1920 e 1950 comportaram muitas modificações, remoções e substituições. O Icomos, seguindo a Carta de Veneza, considera plausível, sim, a exibição de uma etapa anterior, mas apenas em circunstâncias excepcionais em que o elemento eliminado é de pouco interesse e o que é revelado tem grande valor histórico (artigo $11^{\circ}$ ). No caso em tela, não se tratava de remover acréscimos, mas de recompor algo desaparecido, configurando uma ação não contemplada na Carta - que, ao contrário, considera necessário o respeito pelas contribuições válidas de todas as épocas Esse julgamento deve ser feito por equipe multidisciplinar e levar em conta uma série de fatores, entre eles, no caso da igreja, o significado daquela fachada dos anos 1920, modificada nos anos 1950 , para a história da arquitetura brasileira, para a história da intervenção em monumentos no Brasil e para a paisagem e iconografia da cidade. 
21. Para mais dados sobre esse caso, cf. Rykner (2008).

22. Existe uma abundante literatura sobre o tema. Cf., por exemplo, também em caráter de bibliografia complementar, Carvalho (2006), Kühl (2018, p. 91-100), Oksman (2017) e Salvo (2007, 2016).

23. Para uma análise pormenorizada dos artigos da Carta e do ambiente de discussões em que foi gerada, cf. Kühl (2010).

24. Editorial (1984, p. 3). arquitetônicas e ambientes urbanos, permitindo ver sob a lente do restauro, entendido como campo disciplinar, tanto as Ruínas de São Miguel quanto o Paço Imperial. ${ }^{23}$

Mais do que pretender elaborar uma leitura abrangente do que aconteceu naquela década, ou analisar em profundidade os artigos sobre obras específicas, ou mesmo perscrutar os outros textos com o intuito de esgotar as questões neles apresentadas, este artigo pontua alguns dos temas presentes naquele contexto que podem levar a reflexões de interesse, colocando-se, na verdade, como um convite à reflexão e à elaboração de pesquisas ainda por fazer.

\section{A RESTAURAÇÃO NA REVISTA DO PATRIMÔNIO NOS ANOS 1980}

O número 19 da Revista do Patrimônio foi lançado em 1984, após uma interrupção de cerca de meia década, colocou-se, explicitamente, como um "relançamento". Eis o "Editorial" de apresentação do número:

Estamos relançando a Revista do Patrimônio Histórico e Artístico Nacional. Depois de quatro anos de interrupção, ela volta a circular, com novo formato e características editoriais. Da série original, de dezoito números, mantém-se, contudo, o compromisso fundamental com a pesquisa e o debate, firmado por Rodrigo M. F. de Andrade, o fundador do Sphan, ao apresentar, em 1937, a edição de estreia [...].

A publicação - multidisciplinar por excelência e aberta à colaboração acadêmica, inclusive estrangeira - pretende, antes de tudo, incorporar e refletir a inquietação teórica em torno do que é cultura, do que é patrimônio cultural e de como preservá-lo, mesclando artigos especializados à discussão de conceitos e ideias de interesse geral.

Neste número de relançamento ensaia-se cumprir este objetivo. ${ }^{24}$

Colocar-se como relançamento não é apenas marcar, do ponto de vista cronológico, uma retomada após um período sem publicações: é uma proposta efetiva, pois os objetivos e a estruturação da revista foram completamente reformulados.

Para perceber essa mudança, basta comparar o sumário do número 18, de 1978, que está associado à tradição que vinha desde o número 1, de 1937, composto por sete artigos voltados essencialmente para a divulgação de estudos históricos - sobre artistas, obras, cidades ou acervos -, com o do número 19, com catorze artigos que tratam de temas como a relação espaço-sociedade, centros 
históricos, planejamento urbano e preservação, patrimônio natural, propostas de intervenção, o futuro do patrimônio e também ensaios históricos. ${ }^{25}$

O empenho anterior da Revista do Patrimônio em ampliar o conhecimento sobre a arte e a arquitetura brasileira foi significativo no período de consolidação do Sphan, uma vez que o inventário e os estudos históricos eram essenciais para que o trabalho pudesse se consolidar. A revista tornou-se um dos principais veículos de difusão de ensaios sobre esses temas, os quais permanecem até hoje como referência da maior relevância para a construção dos campos da historiografia da arte e da arquitetura no país. ${ }^{26}$

Ao estudar os textos publicados do número 1, de 1937, ao número 17, de 1969, nota-se que há muito pouco relacionado à preservação, e nenhum dos artigos da revista se refere às restaurações que eram executadas pelo próprio Sphan. De um total de 163 artigos, apenas 5 se referem a temas de preservação, e somente um deles, o de Hannah Levy - "Valor artístico e valor histórico", de $1940^{27}$-, está relacionado com as teorias de restauro. A historiadora da arte de origem alemã ${ }^{28}$ que se transferiu para o Brasil em 1937 e aqui permaneceu por dez anos, mobiliza e dá a conhecer diversas proposições sobre os valores artístico e histórico, explorando esses temas no contexto da historiografia da arte. Nos trechos finais do artigo, ela elabora considerações mais diretamente ligadas à restauração e transparece sua sensibilidade quanto aos conflitos que podem existir entre os valores históricos e artísticos dos monumentos - nesse ponto menciona as críticas a Viollet-le-Duc, justamente por ele não reconhecer as pluralidades de valores numa mesma obra. ${ }^{29}$ Não obstante essas considerações publicadas na revista e a atuação de Levy junto ao Sphan, vários restauros efetuados pelo órgão tinham caráter semelhante às posturas de Viollet-le-Duc, como amplamente evidenciado por diversos autores. ${ }^{30}$ Desconsideravam-se as alterações sofridas no decorrer do tempo e buscava-se voltar a um suposto estado inicial, num período em que o referencial internacional sobre o tema era a citada Carta de Atenas, que indicava o oposto. Em alguns casos houve a imposição sobre o edifício de um estado original hipotético, segundo uma projeção retrospectiva idealizada, e por vezes distorcida, da própria história da arquitetura brasileira, que era ainda muito incipiente e marcada pela visão dos arquitetos modernos sobre o assunto.

O relançamento da Revista do Patrimônio nos anos 1980 traz uma quantidade muito maior de textos voltados diretamente à preservação do que nos números da revista durante a chamada "fase heroica", e a situação muda significativamente: dos 97 artigos publicados nos anos 1980, 56 tratam de preservação num sentido lato $157 \%$ dos artigos, em vez de $3 \%$ no período até 1969) e 14 abordam diretamente o patrimônio edificado.
25. Todos os números da Revista do Patrimônio estão disponíveis no portal do Iphan (Instituto do Patrimônio Histórico e Artístico Nacional, 2019b).

26. Mais uma vez se remete, para a análise do papel da revista, aos textos de Ribeiro (op. cit.), Silva (op. cit.) e Thompson et al. (op. cit.).

27. Cf. Levy (1940).

28. Sobre o papel de Hannah Levy no Brasil, ver, por exemplo, o livro organizado por Adriana Nakamuta (2010). Ver ainda as considerações de Fernanda Fernandes (2016) sobre outro texto de Hannah Levy (1941), acerca das teorias do barroco, publicado no número $5 \mathrm{da}$ Revista do Patrimônio.

29. Levy (1940, p. 191-192).

30. A bibliografia sobre o tema é extensíssima e começou a ser discutida há décadas. Cf., por exemplo, Andrade (1993) e Fonseca (op. cit.). 
31. Cf. Miceli (1987); Arantes (1987); Motta (1987).

32. Cf. Leal (1984).
Há nos anos 1980 uma quantidade muito expressiva de artigos voltados para temas amplos que dizem respeito à preservação, abordando questões como políticas culturais, políticas patrimoniais, antropologia, identidade cultural, memória, preservação e democracia, patrimônio arqueológico, patrimônio urbano, o futuro do patrimônio arquitetônico, preservação de áreas naturais, inventário, bens móveis, além de outros assuntos, como cinema, informática e a continuidade dos estudos historiográficos. Da maior relevância, entre os textos ligados a temas de preservação, são os artigos que apresentam uma releitura crítica da atuação do próprio órgão, a exemplo daqueles que se tornaram referências incontornáveis, como os de Sergio Miceli, Antonio Augusto Arantes e Lia Motta, ${ }^{31}$ que trazem críticas muitas vezes implacáveis. Além do mais, no que diz respeito a este artigo, nessas edições são apresentados dois casos de modo aprofundado, algo que, como mencionado, não acontecera na revista até os anos 1980.

\section{OS ARTIGOS SOBRE AS RUÍNAS DE SÃO MIGUEL E O PAÇO IMPERIAL}

Para a abordagem aqui proposta, serão apresentadas considerações a partir dos artigos sobre a conservação das ruínas da lgreja de São Miguel das Missões e sobre o Paço Imperial do Rio de Janeiro, publicados em 1984, respectivamente, nos números 19 e 20 da Revista do Patrimônio, que depois serão contemporizados com reflexões que aparecem em outros textos desse periódico na década de 1980.

As propostas de conservação das ruínas da Igreja de São Miguel foram apresentadas em artigo de Fernando Machado Leal, arquiteto responsável pela coordenação do projeto. ${ }^{32} \bigcirc$ texto segue uma estruturação que é consolidada nesse campo para divulgar casos de intervenção. Apresenta, preliminarmente, alguns dados para situar os remanescentes do antigo povo de São Miguel no contexto do legado da Companhia de Jesus na região, retomando dados cronológicos e históricos e evidenciando que o objeto da restauração são as ruínas do segundo templo construído no local no século XVIII. $\bigcirc$ autor aborda, ainda que de modo limitado - também pelo fato de não ser o escopo do artigo -, alguns problemas historiográficos, de atribuição da autoria do projeto original e de datação. Passa, depois, à análise da composição da igreja e do complexo. Para tanto, mobiliza fontes primárias e ampla bibliografia, que abarca tanto textos mais antigos quanto a produção científica próxima à data de publicação do artigo.

Em seguida, Leal faz uma descrição das diversas transformações por que passou a igreja ao longo dos séculos, a partir das fontes disponíveis. Examina de 
modo pormenorizado as intervenções no século XX - entre 1925 e 1927; entre 1938 e 1940; em 1954; e entre 1967 e 1970 -, tanto a partir de relatórios quanto 34. Ibid., p. 84 de fotos e indagações diretas sobre o monumento, em busca de evidências na própria obra para confirmar hipóteses e informações constantes na documentação. ${ }^{33}$

autor apresenta, então, o estado das ruínas nos anos 1980, evidenciando o processo que deflagrou as ações após o desmoronamento em 1978, que ensejou novas medições, estudos minuciosos, consultas aos mais variados técnicos, empresas e laboratórios especializados, com destacada atuação do consultor da Unesco, Roberto Di Stefano, ${ }^{34}$ que teve papel relevante na elaboração do termo de referência e na estruturação das etapas de trabalho.

Leal descreve, na sequência, as etapas de trabalho e os laboratórios e profissionais envolvidos em cada uma delas: a análise histórica; os levantamentos - gráfico, fotográfico e fotogramétrico; as análises dos materiais constitutivos da igreja; as características construtivas; as características estáticas da estrutura; e - controle da progressão da deformação da fachada principal. A partir do resultado dos estudos, passa então à apresentação das causas de arruinamento, examinando cada um dos elementos da edificação - fundações e alicerces, paredes e arcadas, incluindo a torre sineira. ${ }^{35}$

Com base nesse extenso exame, fruto de trabalho multidisciplinar, Leal apresenta conclusões, recomendações e um elenco das providências a serem tomadas para "sustar o progressivo arruinamento do monumento e prolongar sua vida", 36 incluindo a recomposição das alvenarias, as ações sobre alicerces e fundações, e a proteção contra descargas elétricas - cada um desses itens com seus respectivos procedimentos.

$\bigcirc$ artigo de Leal é fruto consciencioso de seu tempo, com alguns aspectos que hoje poderiam ser revistos à luz dos novos estudos historiográficos sobre as Missões que se avolumaram nas últimas décadas, de métodos avançados de diagnóstico que então não existiam, de novos materiais, métodos e sistemas para consolidação. $\bigcirc$ texto recomenda, por exemplo, o recurso ao concreto armado para amarrações da alvenaria, ${ }^{37}$ uma técnica que ainda é utilizada; mas também existem, hoje, outros meios que têm incidência menor sobre a consistência do bem e desempenho mais adequado e longevo. Quanto à aproximação metodológica, à prudência e à forma meticulosa de enfrentar as questões, o artigo mostra sintonia com o que havia de mais conservativo e informado na época.

No que respeita à explicitação do processo e às motivações do restauro, serão pontuados dois aspectos. Um deles é que o autor em nenhum momento levanta questionamentos sobre a forma de abordagem do monumento, mas toma como premissa que a ruína deva ser conservada como tal - o que absolutamente 
38. Ibid., p. 95. A citação provém de Mayerhofer (1969, p. 9).

39. Cf. Leal (1984). não é um problema; pelo contrário, o que se quer evidenciar é que Leal não explicita no artigo o porquê disso. $\bigcirc$ outro aspecto é o modo como o autor conclui o artigo, isto é, com uma citação em que assemelha a visão de outro autor à sua, sem tampouco discorrer sobre o tema:

Essas medidas de ordem geral, cabe-nos acrescentar, poderão sofrer as modificações que se façam necessárias no decorrer das obras. Como tão bem observou Lucas Mayerhofer: "os processos de restauração se confundem com a prática de execução. Não é razoável, nem oportuno querer sistematizar nem fixar normas.

Não há norma fundamental para restauração. Diante do monumento, ele próprio é o mestre; para quem estuda detidamente um monumento, e o interroga com severidade de historiador, paixão de artista e amor de arquiteto, qualquer restauração se determina particularmente por si mesma". ${ }^{38}$

É interessante notar como ele apresenta de modo "pacificado" questões e dilemas enfrentadas no restauro, que abrangem desde o partido de projeto la conservação como ruína) até decisões técnicas. Por mais aprofundados que sejam os estudos feitos, alguns elementos são verificáveis apenas em canteiro, entre eles o próprio comportamento da obra diante dos trabalhos executados, como o próprio autor explicita. ${ }^{39}$ Mas a estruturação das análises a serem feitas e as decisões técnicas decorrentes do diagnóstico estão longe de serem banais, e daí - cuidado do autor em apresentar o caminho seguido para aprofundar o conhecimento sobre o bem e descrever as soluções adotadas.

A citação que encerra o texto parece uma forma de o autor mostrar a importância de respeitar e perscrutar o monumento com cautela, mas Leal não se estende no assunto: a proposta do artigo é prevalentemente narrar o processo e apresentar as escolhas técnicas, e não problematizá-las. Ao terminar com uma citação, sem fazer outras considerações, Leal deixa em aberto possibilidades de interpretação alheias àquilo que construiu ao longo do artigo. Uma das formas de leitura do parágrafo final seria a de uma abordagem predominantemente empírica da obra, partindo unicamente do monumento, que por si só daria as respostas do rumo a ser dado ao restauro. Na construção do artigo, porém, Leal faz exatamente o contrário: baseia-se em procedimentos metodológicos de aproximação do monumento consolidados no campo da restauração, para depois se voltar às particularidades da obra, indagando-a em profundidade.

A citação também poderia dar a entender que há uma relação unívoca causa-efeito entre problemas e soluções, quando, na realidade, as soluções são mediadas por aquilo que motivou a preservação do bem no estado arruinado 
e pelos princípios e objetivos da restauração pretendida. Para deter um arruinamento progressivo e prolongar a vida da obra naquele estado, as decisões não são corriqueiras, e o próprio artigo mostra isso. Por fim, a citação também pode deixar antever um fenômeno de imanência em que o monumento "determina" o que deve ser feito, quando, na verdade, as respostas às indagações sobre a obra dependem das questões que são formuladas, que, por sua vez, são originadas pelas motivações e pelos objetivos da restauração.

É importante lembrar que o consultor desse processo, Roberto Di Stefano, foi figura de grande importância na ltália e internacionalmente em questões de restauro, teóricas e práticas. Professor da Universidade Federico II de Nápoles, era muito ligado a Roberto Pane, um dos promotores da Carta de Veneza. Di Stefano foi personagem proeminente no lcomos desde a sua fundação, em 1965, e consultor pela Unesco em diversas missões. Estava ligado a uma linha de pensamento que ressignifica o "cada caso é um caso" do restauro, buscando afastar esse dístico do casuísmo e do empirismo pedestre, a que esteve muitas vezes associado, para filiar a ação ao pensamento crítico e científico do período em que é feita a intervenção. ${ }^{40}$

texto sobre a lgreja de São Miguel das Missões não levantou maiores celeumas nos números da Revista do Patrimônio daquela década, pois a preservação do monumento naquele estado era algo aceito e assegurado pelo próprio Sphan desde seus primórdios, já que inscreveu os remanescentes do povo e as ruínas da lgreja de São Miguel no Livro do Tombo das Belas Artes em 1938. Basta lembrar as obras de estabilização e a construção de um Museu no sítio, entre 1938 e 1940, descritas no artigo de Leal, ${ }^{41}$ com propostas de Lucio Costa $^{42}$ e obras conduzidas por Lucas Mayerhofer. $\bigcirc$ Paço Imperial também foi tombado em 1938, no Livro do Tombo Histórico. ${ }^{43} \bigcirc$ caso do Paço, porém, mostrou-se mais problemático e levantou muitas polêmicas dentro do próprio órgão e na Revista do Patrimônio naquele mesmo período.

$\bigcirc$ Paço Imperial, assim como a Igreja de São Miguel das Missões, é chamada principal e objeto da capa da revista. Mas, diversamente do caso de São Miguel, que está presente apenas num artigo de autoria individual - ainda que substancioso, com 27 páginas ${ }^{44}$-, o Paço é abordado na seção Projetos, num dossiê de 54 páginas inteiramente dedicadas a ele e à Praça XV. Há dois artigos e um depoimento sobre a Praça - o de Dora Alcântara, com um estudo histórico da área da Praça XV e imediações; o de Augusto Ivan, sobre as intervenções na Praça XV; e um ensaio de João Antônio ("Praça XV, ai!") -, e cinco artigos sobre a restauração do Paço Imperial: o de Pedro Calmon, "Paço Imperial: história e ressurreição de um palácio"; 45 o de Glauco Campello, "A restauração do Paço: revendo 240 anos de transformação"; 46 o de Cyro Corrêa Lyra, "O novo Paço: uma obra para debates"; 47 o de José de Souza Reis, "Estudos preliminares para a
40. Sobre a produção de Di Stefano e a repercussão de suas propostas e atuação, cf. Aveta e Di Stefano (2014).

41. Leal (1984, p. 81).

42. Lembre-se que Lucio Costa trataria da Igreja de São Miguel das Missões, do ponto de vista da história, em seu artigo "A arquitetura dos jesuítas no Brasil" (Costa, 1941), publicado na Revista do Patrimônio, no qual não discute as obras e propostas dele próprio para o complexo.

43. Informações disponíveis na Lista e bens tombados e processos de tombamento 25-11-2019 (Instituto do Patrimônio Histórico e Artístico Nacional, 2019a).

44. No número 19, existem dois artigos na seção Projetos: o de Fernando Leal (1984) dedicado a São Miguel e o de Jurema K. E. Arnaut (1984) sobre o Morro da Conceição no Rio.

45. Cf. Calmon (1984). 46. Cf. Campello (1984). 47. Cf. Lyra (1984). 
48. Cf. Reis (1984).

49. Cf. Silva; Morley; Silva (1984).

50. A Praça... (1984, p. 113).

51. Calmon, op. cit., p. $137-$ 138.

52. Ibid., p. 138 restauração do Paço";48 e o de Regina Coeli Ribeiro da Silva, Edna Morley e Catarina Ferreira da Silva, "As pesquisas arqueológicas no Paço: primeiras notas". 49

O dossiê, na sua estrutura, evidencia a relação do Paço com a cidade, pois começa com os estudos históricos sobre a área e examina as intervenções por que passou aquela zona da cidade. É mencionada, na página de apresentação do dossiê, a existência de controvérsias em relação à obra realizada no Paço. No entanto, não se explicitam quais seriam as controvérsias, e a solução delas é quase uma premissa do dossiê, que, de saída, desqualifica a face anterior do Paço resultante das obras feitas no início do século XX, caracterizando-a como adulteração:

O edifício, adulterado para o neocolonial no início deste século, retoma a imagem barroca da época de D. João, após dois anos de obras que suscitaram, entre controvérsias e concordâncias técnicas, um legítimo debate interno sobre conceitos e métodos de restauração. ${ }^{50}$

Ou seja, a abertura do dossiê menciona a existência de polêmica, mas já the dá resposta. Nos artigos que se seguem, apesar de serem apresentadas as justificativas dos autores para o partido adotado, não são ouvidas outras vozes - algumas das quais vão ressurgir, na verdade, no número 22 da revista, de 1987 (tema a ser retomado adiante).

O artigo de Pedro Calmon, então presidente do Instituto Histórico e Geográfico Brasileiro e membro do Conselho Consultivo da Subsecretaria do Patrimônio Histórico e Artístico Nacional, é centrado na história e descrição do Palácio. No título ele já deixa entrever sua postura ao falar em "ressurreição", e assim continua:

Sofreu o prédio diversas reformas, a última das quais, na presidência de Washington Luís, o desfigurou, dando-the um terceiro pavimento inteiriço, em boa hora removido na atual obra de restauração que devolve o Paço ao que era em 1821, segundo documenta a preciosa gravura do cônsul inglês Chamberlain. ${ }^{51}$

Transparece no texto uma análise que valoriza a imagem do Paço na transição do Brasil Colônia para o Brasil Império, em detrimento da imagem da obra no Brasil República do século XX, acentuando o desprezo pela forma neocolonial: "eis que a Sphan tomou corajosamente (e inteligentemente) nas mãos o vetusto, o desprezado, o enjeitado Paço da Cidade, e agora o restaura na dignidade da arquitetura primitiva. Restitui-the o feitio nas medidas próprias". 52 Mais do que valorizar determinado período político-administrativo, a motivação 
da proposta parece ser principalmente de cunho formal, pois nos outros artigos aparece também a condenação do neocolonial da fachada do século XX.

No artigo de Glauco Campello, ${ }^{53}$ arquiteto e coordenador do projeto de restauração do Paço, enquanto diretor da $6^{a}$ Diretoria Regional da Sphan, apresenta-se a restauração: são pontuadas questões de método e explicitados o partido projetual e as escolhas feitas. De grande interesse é a forma como o texto mostra que as diversas intervenções ao longo do tempo formaram um complexo intrincado e de difícil compreensão. Foi necessário desenvolver uma gradual aproximação do monumento no canteiro, confrontando os estudos iniciais com a experiência direta na obra, o que em edifícios dessa complexidade é sempre necessário. Como resultado desse processo, o autor afirma:

Depois, à medida que a demolição dos acréscimos ia revelando aspectos surpreendentes de sua dignidade antiga e relações espaciais novas, passando a entender com mais clareza o material histórico e iconográfico à disposição. Tornara-se então irresistível a atração pela integridade de sua imagem barroca representada nas gravuras antigas. ${ }^{54}$

Reconhecendo o sempre salutar método de aliar a ação empírica do canteiro à pesquisa histórico-iconográfica, que se alimentam reciprocamente, o autor continua a reiterar a pertinência de restituir a "imagem barroca" do monumento ao mencionar que José de Souza Reis e Gilberto Ferrez:

foram os primeiros a se deixarem atrair por esta força imanente. Opinaram de saída pela recomposição da volumetria correspondente ao período colonial. Ferrez argumentava ter sido aquele o momento mais importante na trajetória do Paço [...]. Reis não propunha a reconstituição de trechos já desaparecidos, mas a eliminação dos acréscimos que vieram a sufocar a força daquela imagem. Foi esse, praticamente, o rumo tomado [...].

Não foi, contudo, uma decisão fácil seguir o caminho de liberar o arcabouço oitocentista daqueles acréscimos introduzidos pela reforma neocolonial de 1929. Afinal, fora aquela uma intervenção de vulto, representativa, quiséssemos ou não, de um momento da história sociocultural do monumento. Ironicamente, as obras de 1929, apesar de salvarem a sua estrutura básica, transformaram a edificação num outro objeto, adotando um estilo cuja principal característica era a de reviver o vocabulário formal do período colonial. ${ }^{55}$

É importante notar a insistência na imanência da imagem oitocentista, tanto nessa citação quanto no decorrer do texto, 56 algo que perpassa também pelo artigo de Cyro Corrêa Lyra, ${ }^{57}$ arquiteto da Divisão de Tombamento e Conservação da então Sphan, num período em que a "imanência" de objetos era algo fortemente
53. Cf. Campello, op. cit.

54. Ibid., p. 142.

55. Ibid., p. 143 .

56. Ibid., p. 144.

57. Cf. Lyra, op. cit. 
58. Cf. Toledo (1984); Meneses (1984).

59. Cf. Arantes (1987); Miceli (1987).

60. Cf. Campello, op. cit.

61. Carta de Veneza..., op. cit., p. 107. contestado pela historiografia - esta evidencia que não se trata da imanência de objetos, mas de construções de uma dada contemporaneidade, com atribuição de sentidos e significados. Para ilustrar essa posição, basta ver outros textos da mesma revista naquela década, como os de Benedito Lima de Toledo e Ulpiano Bezerra de Meneses, ${ }^{58}$ bem como dos citados Arantes e Miceli. ${ }^{59}$

Para além de não explicitar melhor as características "barrocas" da imagem oitocentista - algo que precisaria ser examinado com mais rigor, à luz das contribuições da história da arquitetura -, ou o papel do neocolonial como expressão artística de um período, Campello constrói depois um raciocínio segundo o qual a questão seria, então, "preservar" ou "restaurar". ${ }^{\circ}$ Preservar seria manter a face neocolonial, enquanto restaurar seria recompor a face oitocentista, num desvio de sentido flagrante em relação aos conceitos associados às palavras "preservar" e "restaurar" neste campo disciplinar. Como dito, desde finais do século XIX o campo do restauro se afasta da volta a um estado original ou precedente, sendo este, portanto, um sentido totalmente contrário às definições da disciplina em âmbito internacional desde a década de 1930, com a Carta de Atenas; algo explicitado também, como mencionado, na Carta de Veneza, de 1964. Ou seja, na visão ałual e na visão dos anos 1980 do campo disciplinar do restauro, a volta a um suposto estado original ou a fases anteriores não é algo a ser buscado.

A remoção de adições que comprometem a sobrevivência da obra Imateriais inadequados, como remendos de cimento em argamassas à base de cal) ou que obliteram sua percepção está prevista na Carta de Veneza, que circunscreve, porém, a pertinência desse tipo de ação:

Artigo $11^{\circ}$ - As contribuições válidas de todas as épocas para a edificação do monumento devem ser respeitadas, visto que a unidade de estilo não é a finalidade a alcançar no curso de uma restauração, a exibição de uma etapa subjacente só se justifica em circunstâncias excepcionais e quando o que se elimina é de pouco interesse e o material que é revelado é de grande valor histórico, arqueológico, ou estético, e seu estado de conservação é considerado satisfatório. $\bigcirc$ julgamento do valor dos elementos em causa e a decisão quanto ao que pode ser eliminado não podem depender somente do autor do projeto. ${ }^{61}$

Não se trata, desse modo, de remover uma fase da obra para recompor e refazer outra. Ou seja, o raciocínio desenvolvido na Carta de Veneza não se aplica ao que foi feito no Paço - a remoção de um andar, a recomposição de uma face perdida etc. -, apesar de algumas remoções no pátio, por exemplo, serem justificáveis à luz dos princípios da Carta. 
Campello continua afirmando que "o que legitima o processo é sua identificação com aspirações sociais e culturais de hoje", 62 sem explicitar de que forma essas aspirações foram ouvidas pelos autores da proposta.

José de Souza Reis - arquiteto da então Sphan que elaborou, juntamente com Gilberto Ferrez (pesquisador, historiador, fotógrafo e colecionador), os estudos iniciais para a restauração do Paço - e Cyro Corrêa Lyra também insistem na recomposição da fachada oitocentista. Lyra afirma que a "'presença' do antigo Paço se impunha"63, depois de mencionar que algumas pessoas tinham "posição apriorística em favor da conservação da fisionomia arquitetônica neocolonial"64 - note-se que, no dossiê sobre o Paço, não foi dada voz a nenhum daqueles que tinham dita posição.

É interessante pontuar certa confusão, nesses artigos, de conceitos e de valores no que respeita à forma como são entendidos os temas preservação e restauro nesse campo disciplinar. Em tais processos, o fio condutor é a permanência, sempre com consciência de que as coisas se alteram com o tempo, queiramos ou não, e de que a própria percepção e recepção dos bens também muda, sendo a transformação, portanto, inerente a processos de preservação. A questão é como abordar essa mudança. No campo disciplinar do restauro, respeitar as várias etapas de uma obra de fato é um princípio que, no caso do Paço, colidiu com algo que para os autores dos artigos foi assumido como uma premissa: a recomposição da face oitocentista, ação que não configura restauro, na forma que é entendido no campo disciplinar, como mencionado anteriormente.

Apesar de o ecletismo do salão da claraboia ${ }^{65}$ ter sido preservado, existe nos textos também um descompasso com as discussões historiográficas da época, em que o ecletismo começa a ser valorizado no país. Naquele período, estudos importantes sobre esse estilo começam a ser divulgados, inclusive na própria Revista do Patrimônio, em 1984, ${ }^{60}$ ano também do II Congresso Nacional de História da Arte, dedicado ao neoclássico e ao ecletismo, que depois deu origem a um livro organizado por Annateresa Fabris ${ }^{67}$ que foi um divisor de águas.

\section{ALGUNS CONTRAPONTOS}

A percepção de temas de preservação e restauro nos números da Revista do Patrimônio na década de 1980 está longe de poder ser assimilada ao discurso publicado em torno do Paço Imperial.
62. Campello, op. cit., p. 143.

63. Lyra, op. cit., p. 153.

64. Ibid., p. 152.

65. Campello, op. cit., p. 146-147.

66. Cf. Figueiredo Filho (1984).

67. Cf. Fabris (1987). 
68. Como mencionado anteriormente, a trajetória do Iphan tem sido explorada de modo aprofundado por diversos autores, tanto em artigos quanto em teses e livros, cuja retomada não cabe neste artigo. Apenas a título de exemplo, cf. Chuva (op. cit.), Sant'Anna (op. cit.) e Marins (op. cit.). Para uma leitura recente do Iphan na própria Revista do Patrimônio, ver as diversas contribuições presentes no número 35, de 2017. Sobre Magalhães e Soeiro, cf. Azevedo (2017) e Anastassakis (2017).

69. A intensão inicial era que o curso fosse ministrado em versões sucessivas, em lugares distintos, a fim de dar oportunidades aos profissionais das diversas regiões do país. O curso foi depois oferecido no Recife, em 1976; em Belo Horizonte, em 1978; e em Salvador, em 1980, onde permaneceu na Universidade Federal da Bahia. Para saber da estruturação dos cursos, de suas motivações, antecedentes e desdobramentos, ver a minuciosa análise de Nascimento (2016).

70. Cf. De Varine-Bohan (1974).

71. Para dados sobre o curso e programas, ver Mayumi (2008, p. 148-155) e Nascimento (op. cit.).

72. Leal (1977, p. 131).

73. Cf. Nascimento (op. cit.).

74. Cf. Parent (1984); Barthélemy (1984).
A já mencionada abertura da revista a temas mais amplos de preservação não é fruto apenas de uma vontade editorial, mas fazia parte das discussões do temário sobre preservação no Brasil, com revisões críticas, alargamento de percepções e distintas formas de atuar que vinham se amplificando e consolidando desde as gestões de Renato Soeiro (1967-1979) e Aloísio Magalhães (1979-1982). .88

São também significativos os cursos de pós-graduação realizados na década de 1970. O primeiro deles, o curso de Restauração e Conservação de Monumentos Arquitetônicos, foi ministrado em 1974, na FAUUSP, a partir da articulação da Secretaria de Cultura, Esportes e Turismo do Estado de São Paulo, envolvendo o Conselho de Defesa do Patrimônio Histórico, Arqueológico, Artístico e Turístico, o lphan e a Universidade de São Paulo, e contando também com a presença de profissionais do exterior, em especial os vinculados à Unesco. ${ }^{69}$ Esses cursos contribuíram para o alargamento do debate - em questões ligadas à antropologia, à sociologia e à escala urbana e territorial - e para uma aproximação dos preceitos divulgados através das cartas do Icomos. A Carta de Veneza fazia parte da bibliografia utilizada por Hugues de Varine-Bohan, que lecionou no curso e trabalhou com o alargamento da noção de patrimônio histórico e artístico para a noção de patrimônio cultural. ${ }^{70} \bigcirc$ mesmo documento foi também perscrutado nas aulas de Augusto da Silva Telles. ${ }^{71}$

É interessante notar que o mesmo Fernando Machado Leal, que foi o responsável pela ação conservativa das rúnas da lgreja de São Miguel e professor do curso, diz seguir as recomendações da Carta de Atenas e da Carta de Veneza e define a restauração como "fazer voltar a edificação à sua feição primitiva", 72 em flagrante contradição com as definiç̃ões de ambas as cartas. Essa contradição pode vir do fato de a noção de restauro proposta na Carta de Veneza ser muito diversa daquilo que comumente foi feito no Brasil ao longo do século XX, de modo que as implicações das propostas desse documento não tenham sido percebidas pelo autor. Flávia Brito do Nascimento perscrutou em profundidade a estruturação do curso e os descompassos entre algumas das discussões apresentadas pelos professores e a prática corrente do restauro no Brasil, evidenciando os estranhamentos que isso provocou nos participantes. ${ }^{73}$

É importante relembrar esse fato para mostrar, mais uma vez neste texto, que a concepção de restauro, como entendido no campo disciplinar, não teve uma aceitação linear e homogênea - não apenas no Brasil, mas em diversos ambientes culturais.

Nesse contexto de efervescência de discussões, não podemos esquecer aquilo que aparece na própria Revista do Patrimônio, tanto na voz de autores internacionais - como Michel Parent, em texto sobre o futuro do patrimônio arquitetônico, ou Jean Barthélemy, discutindo critérios, conservação integrada e preservação na escala urbana e territorial ${ }^{74}$ - quanto de diversos autores nacionais, como os citados Toledo, Bezerra de Meneses, Motta, Arantes e Miceli. 
No que concerne a releituras críticas da atuação do órgão federal que 75. Cf. Miceli, op. cit. citam nominalmente o que ocorreu no Paço Imperial, vale retomar o texto de Miceli, 76. Ibid., p. $44-45$. que já no título - "Sphan: refrigério da cultura oficial"75 - mostra que tratará do tema sem condescendência ou meias-palavras. Quanto à forma como o órgão conduzia as intervenções no patrimônio, diz o autor:

A modalidade técnica escolhida para o trabalho de restauração enquadra-se nessa mesma lógica de embelezamento do estilo e consequente diluição das marcas sociais. Apesar das afirmações em contrário, a tradição preservacionisła no Brasil nunca conseguiu superar a orientação doutrinária consagrada por Viollet-le-Duc, defensor da chamada "reintegração estilística", que não é outra coisa senão o delírio de "purificar" o prédio em vias de restauração de quaisquer acréscimos posteriores à sua construção original. O leitor pouco versado em assuntos de patrimônio poderá comprovar isso visitando algumas das igrejas restauradas na região norte-nordeste, o Paço Imperial na Praça XV do Rio de Janeiro ou, então, qualquer trabalho de restauração arquitetônica guiado pela obsessão em recuperar o ambiente original, depurando-o dos vestígios das atividades ali desenvolvidas no correr de séculos. ${ }^{76}$

Notem que esse artigo foi divulgado apenas três anos após a publicação do caso do Paço. Miceli continua:

Mais recentemente, como por exemplo na restauração do Paço Imperial, os responsáveis pela obra procuraram sinalizar através de tabuletas os expurgos levados a cabo ao longo do trabatho, dando ao menos alguma informação sobre os usos históricos sucessivos do espaço em questão. No limite, tal postura redunda na construção de uma fantasia perfeccionista bastante dissociada da memória que podem ter os habitantes da vizinhança ou aqueles setores da comunidade cuja própria história de vida tenha alguma ligação com o espaço restaurado. Por outro lado, não se sabe bem por que a restauração de espaços arquitetônicos deva se pautar por critérios estilísticos tão puristas e não por uma orientação mais instrumental, a exemplo daquela aplicada na manutenção de outras modalidades de acervo. Afinal, do ponto de vista da sociedade dos vivos, os monumentos podem e devem ser preservados a título estritamente precário, indicativo e documental, não se podendo acreditar na ilusão de estarmos hoje enxergando o Paço tal qual existia nos tempos de D. João VI. "Se Versalhes falasse" é uma utopia reacionária e saudosista e não uma façanha para o bico de técnicos em restauração.77

A construção no campo disciplinar da restauração, como mencionado, foi no sentido de combater exatamente aquilo que Miceli condena na abordagem do Paço. Ou seja, contrapõe-se a não considerar a obra assim como foi estratificada no tempo e à falta de respeito por seus aspectos documentais e sua inserção na vida sociocultural quando da restauração, enfatizando a necessidade de ouvir mais vozes além daquelas dos responsáveis diretos pela intervenção. Esse esforço está consubstanciado na Carta 
78. Diversos autores se dedicam hoje a alargar a interpretação da Carta de Veneza para aquilo que passou a ser considerado como bem cultural, em que aspectos memoriais e simbólicos adquirem papel cada vez mais proeminente. Essas propostas se voltam a entender $\mathrm{e}$ respeitar aquilo em que esses aspectos se consubstanciam na obra, que continua a ser entendida também como fato material e como documento. Cf., por exemplo, também para bibliografia complementar, Carbonara (1997, 2018) e Kühl (2018).

79. Cf. Brandi (2004).

80. Para uma discussão mais aprofundada desse contexto de debates e uma bibliografia específica sobre esses temas, ver: Carbonara (1997, p. 230-390); Kühl (2010); Kühl (2018, p. 59-100).

81. Sigla do International Centre for the Study of the Preservation and Restoration of Cultural Property, organização intergovernamental de Estados-membros que tem colaboração formal com diversas instituições, entre elas a Unesco e o Icomos.

82. Mais uma vez, remete-se a Kühl (2010) e Pane (2011) para uma análise pormenorizada e circunstanciada da Carta e de seus artigos. É relevante notar que os princípios da Carta são aplicáveis também a ruínas resultantes de conflitos bélicos. Esse tema foi abordado por Roberto Pane (1971) na conferência de abertura do Congresso, em que menciona o caso de Varsóvia - que teve seu centro devastado na Segunda Guerra e foi refeito com as feições antigas -, algo que ele entendia como exceção justificável. Segundo Pane (ibid.), somente em caso de devastações é possível justificar que os princípios regentes de Veneza, que foi traduzida para o português no número 22 da Revista do Patrimônio - o mesmo do artigo de Miceli e o último publicado nos anos 1980.78

A Carta de Veneza, como mencionado, foi resultado de encontro científico realizado em 1964 naquela cidade, o II Congresso Internacional de Arquitetos e Técnicos de Monumentos Históricos. A Carta é fruto de um processo plurissecular de discussões sobre a restauração de bens culturais, sendo devedora, em especial, do amadurecimento do debate do campo em função das devastações ocasionadas pela Segunda Grande Guerra, a partir de diversas especulações teóricas, como as de Cesare Brandi, consubstanciadas em numerosos escritos, 79 e o chamado "restauro crítico", que tem entre seus expoentes Renato Bonelli e Roberto Pane. ${ }^{80}$ Essas discussões ocorreram em diversos ambientes culturais e mobilizaram numerosos autores que participaram ativamente do Congresso, entre eles os belgas Raymond Lemaire, que foi o relator da Carta, Paul Philippot, que trabalhava no 1 ccrom, ${ }^{81}$ além dos italianos Piero Gazzola, que presidiu a comissão de redação e foi um dos organizadores do evento, e Roberto Pane, que proferiv a conferência inaugural. Quando o lcomos foi criado, em 1965 - sendo sucessivamente acolhido como órgão consultor e de colaboração pela Unesco -, tomou a Carta de Veneza como seu documento-base.

A Carta, essencialmente, preconiza o respeito pela obra do modo como foi estratificada no tempo, em seus aspectos materiais, de conformação e documentais - princípio válido para escavações arqueológicas, obras arruinadas, obras arquitetônicas isoladas e sítios urbanos ou rurais. ${ }^{82}$ Os debates no número 22 da Revista do Patrimônio, reportados a seguir, tomam a Carta de Veneza como uma de suas bases de discussão, lembrando que seus princípios se aplicam tanto às Ruínas de São Miguel quanto ao Paço. Quando da publicação dos artigos sobre essas obras, a Carta de Veneza completava duas décadas de existência e pelo menos dez anos de discussão aprofundada no Brasil (nos citados cursos da década de 1970, que tiveram o Iphan entre seus promotores). Ou seja, não seria possível alegar desconhecimento de seu conteúdo, o que não significa que seus princípios fossem (ou sejam) efetivamente compreendidos e respeitados, como já dito.

Nesse mesmo número há cinco mesas-redondas de grande interesse: uma sobre o tombamento; a segunda voltada à conservação e restauração do patrimônio edificado; outra aos sítios históricos e núcleos urbanos; uma quarta voltada ao patrimônio arqueológico; e a última delas ao patrimônio natural.

Serão pontuados a seguir alguns temas que surgiram na mesa sobre conservação e restauração do patrimônio edificado, mais afeita aos temas propostos neste artigo. Participaram da mesa três membros da Sphan - Antônio Pedro Alcântara, Augusto da Silva Telles e Lia Motta -, um professor da Universidade 
Federal da Bahia, Carlos Alberto Reis Campos, e o presidente do Instituto Estadual do Patrimônio Histórico e Artístico de Minas Gerais, Rodrigo Andrade. ${ }^{83}$

Mais do que explorar o pensamento de cada autor, aqui serão elencados apenas os temas de fundo das discussões, que passaram por questões como: a competência da Federação, dos estados e municípios; a pressão da especulação imobiliária e da política; por que e para quem preservar, como preservar e qual o seu uso adequado; e o papel das diversas profissões envolvidas na tutela, com críticas à excessiva prevalência de arquitetos. Cada autor tem aproximações de nuanças diversas com cada um desses assuntos. No que se refere às ações diretas nos bens culturais, abordam a Carta de Veneza, louvando o fato de o documento estabelecer critérios. Lia Motta mostra que a Carta, ao preconizar o respeito pela trajetória do monumento no tempo e abarcar a questão do entorno, aponta para uma visão diferente daquilo que era a ação do órgão ${ }^{84}$ - perspectiva que ela aborda e critica mais adiante, no mesmo número. ${ }^{85} \bigcirc$ tema é retomado por Silva Telles, que evidencia a ênfase da Carta no monumento como objeto histórico, e não apenas como testemunho de uma única fase. Ele invoca também as polêmicas relativas ao Paço Imperial (e outros casos), em que cada profissional tem posição diferente, referindo que, por isso mesmo, a Carta recomenda que a restauração não seja obra de um único arquiteto ${ }^{86}$ - ponto reiterado por Reis Campos. Alcântara enfatiza, porém, que não se trata apenas de não depender unicamente de um profissional, mas de evitar qualquer intervenção destruidora, conforme explicitado na Carta, que deu um basta em ações dessa natureza. Alcântara ainda afirma achar estranho o fato de as diretrizes de operação da Sphan, então com sete anos, não serem respeitadas, e ainda mais estranho que a Carta de Veneza, com 22 anos, não seja seguida. ${ }^{87}$

Transparece, em todas as falas, um ambiente vivo de inquietações, incluindo as já invocadas preocupações quanto às pressões vindas da política e da especulação imobiliária e quanto à necessidade de evitar a arbitrariedade, tornando-se necessário que a restauração tenha uma aproximação metodológica rigorosa e pautada por critérios claros.

\section{CONSIDERAÇÕES FINAIS}

As questões do restauro no Brasil na década de 1980, vistas neste artigo a partir da Revista do Patrimônio, abrangem um vasto temário e pautam problemas que continuam candentes até os dias de hoje, exigindo que continuemos a refletir criticamente. da restauração cedam ao refazimento que retoma formas anteriores, isto é, como modo de ajudar determinadas comunidades a recompor sua vida psicossocial depois de traumas enormes. Mas isso não autoriza, segundo o autor e do ponto de vista da Carta de Vene$z a$, a reconstruir indistintamente obras por que desabaram ou desapareceram de modo traumático; basta, para isso, ver as colocações de Pane (1944) sobre a Igreja de Santa Clara, em Nápoles, para a qual, mesmo com bombardeio, incêndio e trauma de guerra, se preconiza o respeito pela materialidade da obra como foi transformada pelo tempo. A Declaração de Dresden, de 1982, trata dos monumentos destruídos pela guerra e foi fruto de reunião promovida pelo Icomos-Alemanha com a participação de estudiosos de onze países. É um texto de interesse para reflexão, mas vale enfatizar que não faz parte dos documentos adotados pela Assembleia-Geral do Icomos, que hoje tem membros de 107 países ver a hierarquia e organização dos documentos no site da instituição (International Council on Monuments and Sites, c2020).

83. Cf. Alcântara et al. (1987).

84. Ibid., p. 97.

85. Cf. Motta, op. cit.

86. Alcântara et al., op. cit., p. 101.

87. Ibid., loc. cit. 
Naquela década, passamos de uma visão de patrimônio histórico baseada na excepcionalidade, como determinava o Decreto-Lei $n^{\circ} 25$, de 30 de novembro de 1937 - sendo considerados de interesse para a preservação bens vinculados "a fatos memoráveis da história do Brasil, quer por seu excepcional valor arqueológico ou etnográfico, bibliográfico ou artístico" (artigo 1088-, para a visão mais abrangente, diversa e inclusiva da Constituição Federal de 1988, em que constituem o "patrimônio cultural brasileiro os bens de natureza material e imaterial, tomados individualmente ou em conjunto, portadores de referência à identidade, à ação, à memória dos diferentes grupos formadores da sociedade" (artigo 216). ${ }^{89}$

Essa efervescência de ideias num período de profundas transformações está presente nos números da Revista do Patrimônio aqui abordados, que nos mostram ser necessário continuar a refletir sobre aqueles debates e sobre as intervenções realizadas na década de 1980. As questões colocadas são de grande interesse e podem oferecer instrumentos importantes para ler as questões do presente. As reflexões presentes na Revista do Patrimônio naquela década são ainda um marco do nível de apuro das críticas e das proposições nesse campo, de tal modo que também deveriam servir de referência para os debates atuais.

A visão de hoje sobre o restauro é desdobramento de uma longa construção cultural, articulada com a discussão sobre o que é patrimônio e por que ele é preservado - algo que sempre variou e varia ao longo do tempo e tem se ampliado continuamente. $O$ interesse dessa disciplina, há tempos, não é voltado apenas a obras excepcionais, mas também a testemunhos do fazer humano que passam a ser considerados de interesse cultural. O restauro é entendido como ato de cultura, pautado no respeito pelos aspectos documentais da obra e pela sua materialidade e conformação, tal como transformadas pelo tempo, como também naquilo que se refere à consubstanciação, na obra, de aspectos memoriais e simbólicos, sendo o todo mediado pelas contribuições de vários campos do saber. É construção sociocultural constantemente sujeita a revisões críticas em função daquilo que é reconhecido como de interesse coletivo, sendo sempre necessário promover uma postura reflexiva e um constante exercício filológico sobre o próprio campo, para evitar, como mostra Varagnoli, 90 recair numa dimensão mítica e autorreferencial.

Os debates e as propostas dos anos 1980 ajudam a refletir sobre o campo do patrimônio nos dias de hoje, sobre os instrumentos de que dispomos e sobre o papel das instituições, com a convicção de que os temas ligados aos bens culturais, à identidade, à memória, à preservação e, por conseguinte, ao restauro são questões de Estado - e não unicamente de governo -, de forma que têm de se afastar de interesses imediatistas e setoriais e contemplar os diferentes grupos formadores da sociedade (como exige nossa Constituição) e o tempo na longa duração. 


\section{REFERÊNCIAS}

FONTES IMPRESSAS

BRASIL. Decreto-Lei $\mathrm{n}^{\circ}$ 25, de 30 de novembro de 1937. Organiza a proteção do patrimônio histórico e artístico nacional. Diário Oficial da União, Rio de Janeiro, p. 24056, 6 dez. 1937. Disponível em: <https://bit.ly/2NyjXNZ>. Acesso em: 16 jan. 2020.

BRASIL. [Constituição (1988)]. Constituição da República Federativa do Brasil de 1988. Diário Oficial da União, Brasília, DF, p. 1, 5 out. 1988. Disponível em: <https://bit.ly/2tnUeky>. Acesso em: 16 jan. 2020.

CARTA de Atenas, de outubro de 1931: Escritório Internacional dos Museus: Sociedade das Nações. Rio de Janeiro: Iphan, 2001. Disponível em: <https://bit.ly/2tqBEbl>. Acesso em: 16 jan. 2020.

CARTA de Veneza: carta internacional sobre conservação e restauração de monumentos históricos. Revista do Patrimônio Histórico e Artístico Nacional, Rio de Janeiro, n. 22, p. 106-107, 1987.

LIVROS, ARTIGOS E TESES

AlCÂNTARA, Antônio Pedro; TELLES, Augusto Silva; CAMPOS, Carlos Alberto Reis; MOTTA, Lia; ANDRADE, Rodrigo. Mesa-redonda: Patrimônio edificado I: conservação/restauração. Revista do Patrimônio Histórico e Artístico Nacional, Rio de Janeiro, n. 22, p. 90-105, 1987.

ANASTASSAKIS, Zoy. A cultura como projeto: Aloisio Magalhães e suas ideias para o Iphan. Revista do Patrimônio Histórico e Artístico Nacional, Brasília, DF, n. 35, p. 65-78, 2017. Disponível em: <https://bit.ly/38hijZd>. Acesso em: 16 jan. 2020.

ANDRADE, Antonio Luiz Dias de. Um estado completo que pode jamais ter existido. 1993. Tese (Doutorado em Estruturas Ambientais Urbanas) - Faculdade de Arquitetura e Urbanismo, Universidade de São Paulo, São Paulo, 1993.

A PRAÇA, o Paço. Revista do Patrimônio Histórico e Artístico Nacional, Rio de Janeiro, n. 20, p. 112-113, 1984. 
ARANTES, Antonio Augusto. Documentos históricos, documentos de cultura. Revista do Patrimônio Histórico e Artístico Nacional, Rio de Janeiro, n. 22, p. 48-55, 1987.

ARNAUT, Jurema Kopke Eis. Morro da Conceição, Rio: uma proposta de preservação sem tombamento. Revista do Patrimônio Histórico e Artístico Nacional, Rio de Janeiro, n. 19, p. 97-111, 1984.

AVETA, Aldo; DI STEFANO, Maurizio (orgs.). Roberto Di Stefano: filosofia della conservazione e prassi del restauro. Napoli: Arte Tipografica, 2014.

AZEVEDO, Paulo Ormindo de. Patrimônio cultural e natural como fator de desenvolvimento: a revolução silenciosa de Renato Soeiro, 1967-1979. Revista do Patrimônio Histórico e Artístico Nacional, Brasília, DF, n. 35, p. 45-64, 2017. Disponível em: <https://bit. ly/38hijZd>. Acesso em: 16 jan. 2020.

BARTHÉLEMY, Jean. Nosso patrimônio no ano 2000. Revista do Patrimônio Histórico e Artístico Nacional, Rio de Janeiro, n. 20, p. 108-111, 1984.

BRANDI, Cesare. Teoria da restauração. Tradução de Beatriz Mugayar Kühl. Cotia: Ateliê, 2004.

BOITO, Camillo. Os restauradores. Tradução de Beatriz Mugayar Kühl. Cotia: Ateliê, 2002.

CALMON, Pedro. Paço Imperial: história e ressurreição de um palácio. Revista do Patrimônio Histórico e Artístico Nacional, Rio de Janeiro, n. 20, p. 134-138, 1984.

CAMPELlO, Glauco. A restauração do Paço: revendo 240 anos de transformação. Revista do Patrimônio Histórico e Artístico Nacional, Rio de Janeiro, n. 20, p. 139-151, 1984.

CARBONARA, Giovanni. Avvicinamento al restauro: teoria, storia, monumenti. Napoli: Liguori, 1997.

CARBONARA, Giovanni. È proprio necessaria una 'nuova teoria' del restauro? Considerazioni sul volume de Salvador Muñoz Viñas. Opus: quaderno di storia architettura restauro disegno, Pescara, n. 2, p. 163-180, 2018.

CARSALADE, Flavio de Lemos. Pedra e o tempo: a arquitetura como patrimônio cultural. Belo Horizonte: UFMG, 2018. 
CARVAlHO, Claudia S. Rodrigues de. Preservação da arquitetura moderna: edifícios de escritórios no Rio de Janeiro construídos entre 1930-1960. 2006. Tese (Doutorado em História e Fundamentos da Arquitetura e do Urbanismo) - Faculdade de Arquitetura e Urbanismo, Universidade de São Paulo, São Paulo, 2006.

CASTRIOTA, Leonardo Barci. Patrimônio cultural: conceitos, políticas, instrumentos. São Paulo: Annablume, 2009.

CHOAY, Françoise. A alegoria do patrimônio. Tradução de Luciano Vieira Machado. São Paulo: Unesp, 2001.

CHOAY, Françoise. O patrimônio em questão. Tradução de João Gabriel Alves Domingos. Belo Horizonte: Fino Traço, 2011.

CHOAY, Françoise. I rapporti fra Ruskin e Viollet-le-Duc, o la lunga vita dei preconcetti. In: CHOAY, Françoise. Patrimonio e globalizzazione. Firenze: Alinea, 2012. p. 47-68.

CHUVA, Márcia. Os arquitetos da memória: sociogênese das práticas de preservação do patrimônio cultural no Brasil (anos 1930-1940). Rio de Janeiro: UFRJ, 2009.

COELHO, Olínio Gomes Paschoal. Convento de Santo Antônio no Rio de Janeiro: restauro e revitalização. Interfaces, Rio de Janeiro, v. 2, n. 28, p. 39-72, 2018. Disponível em: <https:// bit.ly/3c6m4mt>. Acesso em: 16 jan. 2020.

COSTA, Lucio. A arquitetura dos jesuítas no Brasil. Revista do Serviço do Patrimônio Histórico e Artístico Nacional, Rio de Janeiro, n. 5, p. 9-103, 1941.

DE VARINE-BOHAN, Hughes. A experiência internacional: notas de aula 12-9-1974. São Paulo: FAUUSP: Iphan, 1974.

EDITORIAL. Revista do Patrimônio Histórico e Artístico Nacional, Rio de Janeiro, n. 19, p. 3, 1984.

FABRIS, Annateresa (org.). Ecletismo na arquitetura brasileira. São Paulo: Nobel: Edusp, 1987.

FERNANDES, Fernanda. História, preservação e projeto: entre passado e o futuro. Arquitextos, São Paulo, ano 17, n. 195.03, 2016. Disponível em: <https://bit.ly/2TAJIBj>. Acesso em: 16 jan. 2020.

FIGUEIREDO FILHO, Godofredo Rebello de. Ecletismo na arquitetura baiana. Revista do Patrimônio Histórico e Artístico Nacional, Rio de Janeiro, n. 19, p. 15-27, 1984. 
FONSECA, Maria Cecília Londres. O patrimônio em processo: trajetória da política federal de preservação no Brasil. Rio de Janeiro: UFRJ, 1997.

GIOVANNONI, Gustavo. Restauro dos monumentos. In: KÜHL, Beatriz Mugayar (org.). Gustavo Giovannoni: textos escolhidos. Cotia: Ateliê, 2013. p. 191-203.

JOKILEHTO, Jukka Ilmari. A bistory of architectural conservation. Oxford: ButterworthHeinemann, 1999.

KÜHL, Beatriz Mugayar. Notas sobre a Carta de Veneza. Anais do Museu Paulista, São Paulo, v. 18, n. 2, p. 287-320, 2010.

KÜHL, Beatriz Mugayar. Preservação do patrimônio arquitetônico da industrialização: problemas teóricos de restauro. 2. ed. Cotia: Ateliê: Fapesp, 2018.

LEAL, Fernando Machado. Restauração e conservação de monumentos brasileiros: subsídios para o seu estudo. Recife: UFPE, 1977.

LEAL, Fernando Machado. São Miguel das Missões: estudo de conservação e estabilização das ruínas da igreja. Revista do Patrimônio Histórico e Artístico Nacional, Rio de Janeiro, n. 19, p. 70-96, 1984.

LEVY, Hanna. Valor artístico e valor histórico: importante problema da história da arte. Revista do Serviço do Patrimônio Histórico e Artístico Nacional, Rio de Janeiro, n. 4, p. 181-192, 1940.

LEVY, Hanna. A propósito de três teorias sobre o barroco. Revista do Serviço do Patrimônio Histórico e Artístico Nacional, Rio de Janeiro, n. 5, p. 259-284, 1941.

LYRA, Cyro Corrêa. O novo Paço: uma obra para debates, Revista do Patrimônio Histórico e Artístico Nacional, Rio de Janeiro, n. 20, p. 152-154, 1984.

MARINS, Paulo César Garcez. Novos patrimônios, um novo Brasil? Um balanço das políticas patrimoniais federais após a década de 1980. Estudos Históricos, Rio de Janeiro, v. 29, n. 57, p. 9-28, 2016.

MAYERHOFER, Lucas. A Igreja de São Miguel das Missões. Revista do Instituto de Estudos Brasileiros, São Paulo, n. 6, p. 7-32, 1969. Disponível em: <https://bit.ly/35LIYPz>. Acesso em: 16 jan. 2020. 
MAYUMI, Lia. Taipa, canela-preta e concreto: estudo sobre o restauro das cassas bandeiristas. São Paulo: Romano Guerra, 2008.

MENESES, Ulpiano Bezerra de. Identidade cultural e patrimônio arqueológico. Revista do Patrimônio Histórico e Artístico Nacional, Rio de Janeiro, n. 20, p. 33-36, 1984.

MICELI, Sergio. Sphan: refrigério da cultura oficial. Revista do Patrimônio Histórico e Artístico Nacional, Rio de Janeiro, n. 22, p. 44-47, 1987.

MOTTA, Lia. A Sphan em Ouro Preto: uma história de conceitos e critérios. Revista do Patrimônio Histórico e Artístico Nacional, Rio de Janeiro, n. 22, p. 108-122, 1987.

MUÑOZ VIÑAS, Salvador. Teoría contemporánea de la restauración. Madrid: Síntesis, 2004.

NAKAMUTA, Adriana (org.). Hannab Levy no Sphan: história da arte e patrimônio. Rio de Janeiro: Iphan, 2010.

NASCIMENTO, Flávia Brito do. Formar e questionar? Os cursos de especialização em patrimônio cultural na década de 1970. Anais do Museu Paulista, São Paulo, v. 24, n. 1, p. 205236, 2016. Disponível em: <https://bit.ly/2RzesjK>. Acesso em: 20 jan. 2020.

OKSMAN, Silvio. Contradições na preservação da arquitetura moderna. 2017. Tese (Doutorado em História e Fundamentos da Arquitetura e do Urbanismo) - Faculdade de Arquitetura e Urbanismo, Universidade de São Paulo, São Paulo, 2017.

OLIVEIRA, Carolina Fidalgo de. A cidade de Goiás como patrimônio cultural mundial: descompassos entre teorias, discursos e práticas de preservação. São Paulo: Annablume, 2019.

PANE, Andrea. Drafting of the Venice Charter: historical developments in conservation. Dublin: Icomos Ireland, 2011.

PANE, Roberto. Il restauro dei monumenti. Aretusa, Napoli, v. 1, n. 1, p. 68-79, 1944.

PANE, Roberto. Conférence introductive. In: INTERNATIONAL COUNCIL ON MONUMENTS AND SITES. Il monumento per l'uomo: atti del II Congresso Internazionale del Restauro: Venezia 25-31 maggio 1964. Padova: Icomos: Marsilio, 1971. p. 1-12.

PARENT, Michel. O futuro do patrimônio arquitetônico. Revista do Patrimônio Histórico e Artístico Nacional, Rio de Janeiro, n. 19, p.112-123, 1984. 
REIS, José de Souza. Estudos preliminares para a restauração do Paço. Revista do Patrimônio Histórico e Artístico Nacional, Rio de Janeiro, n. 20, p. 155-157, 1984.

REVISTA DO PATRIMÔNIO HISTÓRICO E ARTÍSTICO NACIONAL. Brasília, DF: Iphan, 1937- . ISSN 0102-2571.

REZENDE, Maria Beatriz; GRIECO, Bettina; TEIXEIRA, Luciano; THOMPSON, Analucia. Fundação Nacional Pró-Memória 1979-1990. In: INSTITUTO DO PATRIMÔNIO HISTÓRICO E ARTÍSTICO NACIONAL. Dicionário do patrimônio cultural. Brasília, DF: Iphan, 2014. Disponível em: <https://bit.ly/2WCNIRz>. Acesso em: 14 jan. 2020.

RIBEIRO, Robson Orzari. Revista do Patrimônio Histórico e Artístico Nacional: textos de história da arte engajados na política de preservação no Brasil. 2013. Dissertação (Mestrado em História da Arte) - Instituto de Filosofia e Ciências Humanas, Universidade Estadual de Campinas, Campinas, 2013.

RYKNER, Didier. L'architecte en chef de Fontainebleau a été remercié. La Tribune de l'Art, Paris, 26 dez. 2008. Disponível em: <https://bit.ly/3agJ5CI>. Acesso em: 14 jan. 2020.

SALVO, Simona. Restauro e "restauros" das obras arquitetônicas do século XX: intervenções em arranha-céus em confronto. Revista CPC, São Paulo, n. 4, p. 139-157, 2007. Disponível em: $<$ https://bit.ly/2H50Iew>. Acesso em: 16 jan. 2020.

SALVO, Simona. Restaurare il novecento: storie, esperienze e prospettive in architettura. Macerata: Quodlibet, 2016.

SANT'ANNA, Marcia Genésia de. Da cidade-monumento à cidade-documento: a trajetória da norma de preservação de áreas urbanas no Brasil (1937-1990). 1995. Dissertação (Mestrado em Arquitetura e Urbanismo) - Faculdade de Arquitetura e Urbanismo, Universidade Federal da Bahia, Salvador, 1995.

SILVA, Cíntia Mayumi de Carli. Revista do Patrimônio: editor, autores, temas. 2010. Dissertação (Mestrado em História, Política e Bens Culturais) - Centro de Pesquisa e Documentação de História Contemporânea do Brasil, Fundação Getulio Vargas, Rio de Janeiro, 2010.

SILVA, Regina Coeli Ribeiro da; MORLEY, Edna; SILVA, Catarina Ferreira da. As pesquisas arqueológicas do Paço: primeiras notas. Revista do Patrimônio Histórico e Artístico Nacional, Rio de Janeiro, n. 20, p. 158-165, 1984.

THOMPSON, Analucia et al. História e civilização material na Revista do Patrimônio. Revista do Patrimônio Histórico e Artístico Nacional, Brasília, DF, n. 34, p. 167-197, 2012. 
TOLEDO, Benedito Lima de. Bem cultural e identidade cultural. Revista do Patrimônio Histórico e Artístico Nacional, Rio de Janeiro, n. 20, p. 28-32, 1984.

VARAGNOLI, Claudio. Giovannoni nella casa natale di Croce; con alcune riflessione sull'eredità di Roberto Pane. In: CASIELLO, Stella; PANE, Andrea; RUSSO, Valentina (orgs.). Roberto Pane tra Storia e Restauro: architettura, città, paesaggi. Venezia: Marsilio, 2010. p. 138-142.

SITES

INTERNATIONAL COUNCIL ON MONUMENTS AND SITES. Chartes et autres textes doctrinaux. Icomos, Charenton-le-Pont, c2020. Disponível em: <https://bit.ly/3ijxlwa $>$. Acesso em: 16 jan. 2020.

INSTITUTO DO PATRIMÔNIO HISTÓRICO E ARTÍSTICO NACIONAL. Lista de bens tombados e processos de tombamento 25-11-2019. Brasília, DF: Iphan, 2019a. Disponível em: <https:// bit.ly/32IMto9>. Acesso em: 14 jan. 2020.

INSTITUTO DO PATRIMÔNIO HISTÓRICO E ARTÍSTICO NACIONAL. Publicações. Iphan, Brasília, DF, 2019b. Disponível em: <https://bit.ly/2R29eO1>. Acesso em: 14 jan. 2020.

Artigo apresentado em 17/1/2020. Aprovado em 29/5/2020.

\section{(cc) BY}

